\title{
10
}

\section{INFRASTRUCTURES FOR \\ GLOBAL PRODUCTION IN \\ ETHIOPIA AND ARGENTINA}

\section{Commodity chains and urban spatial transformation}

\section{Elke Beyer, Lucas-Andrés Elsner, and Anke Hagemann}

\section{Global production networks and spatio-material infrastructures}

This chapter investigates the provision of infrastructures for the processing, manufacturing, and global circulation of commodities as a mode of the transnational production of urban space. It focuses on specific architectures and infrastructures that have been developed in Ethiopia and Argentina in recent years in cooperation with international partners — such as railway lines, shipping terminals, or industrial parks. By taking a closer look at infrastructure provision and the actors involved, the chapter aims to build a deeper understanding of the spatio-material dimension of globalized production systems. Physical infrastructures of commodity processing, manufacturing, and circulation create necessary preconditions for exploiting spatial differences and thus shape and (re)produce the spatial patterns of uneven development (Sheppard 2016; Smith 1984). In the following, we chart an agenda for analyzing the provisioning of infrastructures for global production and circulation as spatial interventions that mediate and alter these dynamics, and thus contribute to the refiguration of urban spaces.

In order to study the relational and transnational constitution of spaces of production, urban and architectural research can productively build on commodity chain approaches (Gereffi and Korzeniewicz 1994; Bair 2005), especially the Global Production Networks (GPN) approach (Henderson et al. 2002). The GPN framework places emphasis on studying the dynamic supplier relations of global "lead firms," the territorial dimension of global production networks, and the role of non-firm actors on various scales. Seeking to understand the spatially dispersed organization of industrial production for global markets, proponents of this approach proclaim a strong interest in the regional embeddedness of economic activities (Coe and Yeung 2015). However, GPN research has been criticized for 
falling short of actually "unpacking the nodes" within production networks below the scale of the region (Kleibert and Horner 2018), and also for a lack of attention to the "dark sides" of network inclusion, such as local struggles and polarization, and to disinvestment as a consequence of the constant restructuring of global production networks (Bair and Werner 2011; Werner 2016; Phelps, Atienza, and Arias 2018). If this critique is taken into consideration, the GPN approach offers valuable analytical tools for multi-sited research on the urban impacts of transnational production arrangements (Beyer and Hagemann 2018; Hagemann and Beyer 2020).

In order to fully comprehend the material and processual dimensions of infrastructural constellations on multiple scales, we suggest bringing the GPN framework into conversation with different strands of research on urban development. A valuable counterpoint to the GPN perspective is provided by work in a Marxist political economy tradition, as this strand of literature addresses and theorizes the uneven developmental benefits emerging from a place's connectivity and identifies how they are linked to the physical, built infrastructures of transport (Smith 1984; Sheppard 2016). Fruitful insights on how the provision of infrastructure networks inscribes and reinforces spatial inequalities and transforms urban landscapes and governance regimes have also been offered by recent scholarship on urban infrastructures (Rode, Tereffe, and la Cruz 2020; Kanai and Schindler 2018; Lara 2012; LeCavalier 2016; Cidell 2015; Graham and Marvin 2001), including reflections on how infrastructures transform urban space through their disposition, inscribed logics, restrictions, and possibilities, and thus may be understood as "active objects" (Easterling 2014) shaping urban development trajectories. An integration of commodity chain research and urban research has also been demanded by scholars working on the transnationality of cities (Krätke, Wildner, and Lanz 2012). In this context, Parnreiter (2012) proposes assessing the transnational constitution of urban spaces specifically with regard to the material, built environment and the transnational ways it is negotiated, planned, and constructed. In recent years, an instructive research literature on the translocal constitution of planning knowledge and practices has emerged (Harris 2013; Söderström 2014; Grubbauer 2015).

Building on this spectrum of research literature, we regard specific production environments - infrastructure complexes enabling the circulation and processing of goods within global production networks - as transnational urban spaces. In our view, different scales of analysis are required to build an understanding of how they are constituted and which actors are involved in their making:

- Global production systems, both of commodities and physical infrastructures

- National and international development agendas and policies

- Commodity hubs, i.e. spatial concentrations of industry, logistics, and infrastructure facilities, including the institutions linked to a specific GPN (Giraudo 2015)

- Specific localities and architectures in their respective urban context 
In the next section, we discuss two case studies on commodity hubs and infrastructure provisioning with significant involvement of international actors, specifically from the PR China, with regard to transnational production relations and spatial transformations. In Mekelle, Ethiopia, a large export processing zone has been built with road and rail connections to international sea ports as an aspiring hub of global garment production. The Greater Rosario metropolitan area hosts Argentina's most important ports for soy export and is receiving vast investments in cargo rail and port facilities. The case studies draw on ongoing research, including site visits and stakeholder interviews in Ethiopia (2017 and 2018) ${ }^{1}$ and Argentina (2018).

\section{Case 1: global clothing production and infrastructure provision in Ethiopia}

Ethiopia's current ambitious economic development agenda includes the goal to integrate the country into global production networks, especially of clothing and other light industries (National Planning Commission 2016, Ethiopian Investment Commission 2020). Related to this, major infrastructure developments are under way in cooperation with international partners (Map 10.1). They imply significant spatial transformations on different scales: While transport infrastructure systems of country-wide and transcontinental reach are being built, large export manufacturing zones are being established in the peripheries of major cities, in some cases in parallel to major residential development. In designing and building the physical structures enabling global manufacturing and the required connectivity, the PR China has become Ethiopia's most important international partner, as well as provider of capital and source of foreign direct investment (Jalles d'Orey and Prizzon 2017; Delz 2016; Nicolas 2017). At the time of writing, however, violent intraregional conflicts in Ethiopia are casting doubt on the outcomes of infrastructureled development as well as the future commitment of the notoriously volatile global clothing industry.

Ethiopia is seen as a major market for power and transport infrastructure in sub-Saharan Africa (Delz 2015; Foster and Morella 2011). The road network is being expanded, along with dry port facilities for international freight logistics (UNDP Ethiopia 2017), and a national electric railway network is envisioned. As a first leg, a new $791 \mathrm{~km}$ standard gauge railway between Addis Ababa and the port of Djibouti, the crucial entry and exit point of goods for land-locked Ethiopia, was built by the China Railway Construction Corporation and the China Civil Engineering Construction Corporation (CCECC), and has been operated by a Chinese-Ethiopian company since 2018. A large share of the project was financed by the China Export Import Bank, reportedly involving the import of about USD 1 billion worth of equipment and construction materials from China (Sun 2017). Construction of the second leg, extending nearly $600 \mathrm{~km}$ northwards to Mekelle, was taken up with engineering companies and financial backing from the PR China and Turkey. The railway construction is a strong signal of Ethiopia's commitment to state-led infrastructure development and of Ethio-Chinese cooperation, but its high cost and its actual exigency for textile export producers are subject 


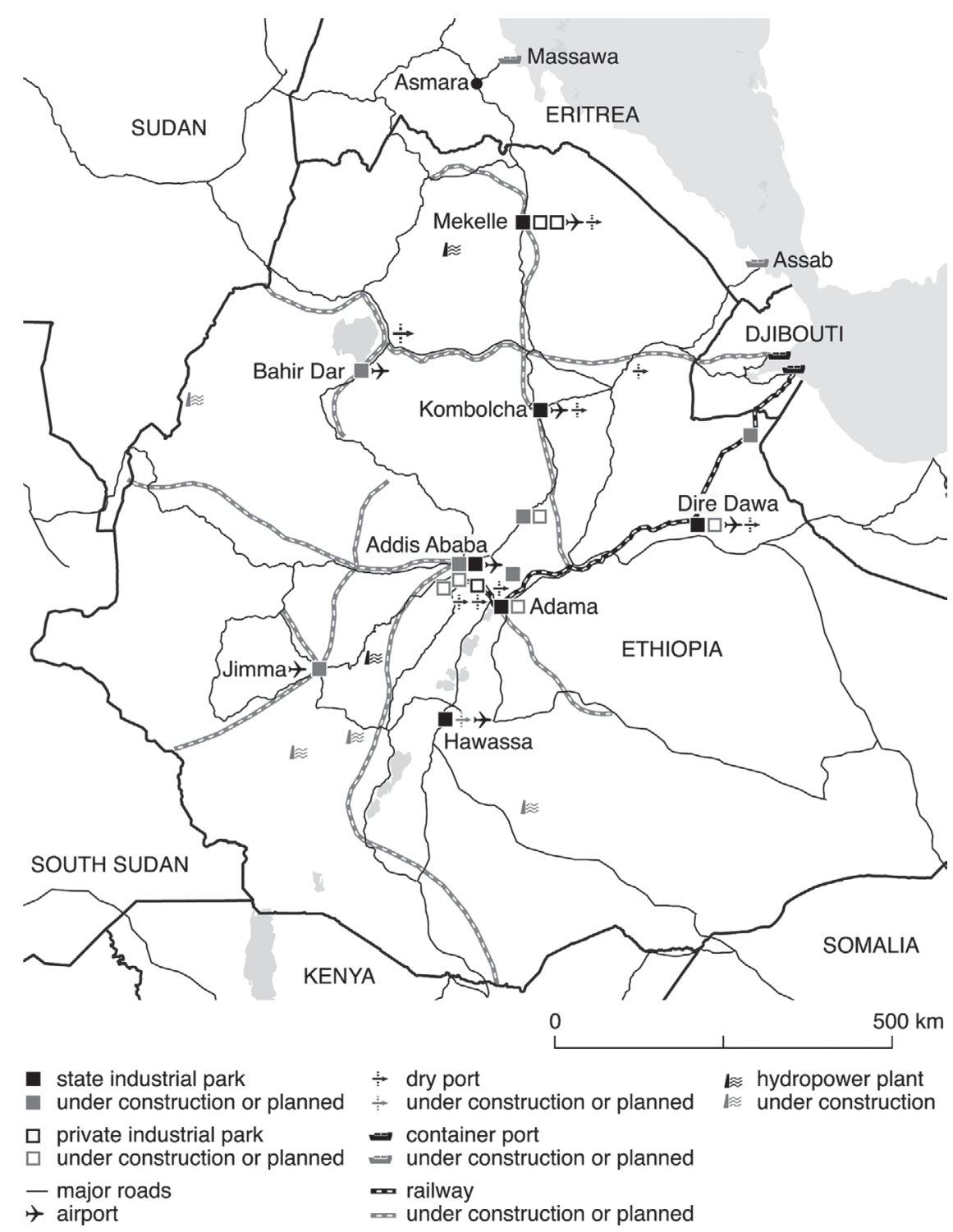

MAP 10.1 Industrial park and infrastructure development in Ethiopia (2018)

Map: Anke Hagemann, Elke Beyer, Rucha Kelkar

Sources: Google Maps, OpenStreetMap, maplibrary.org, Ethiopian Investment Commission, Industrial Parks Development Corporation, Embassy of Ethiopia (Brussels), Ethiopian Shipping Lines

to contrarian debate among transport planners (authors' interviews 2018; see also Rode, Tereffe, and la Cruz 2020).

The Ethiopian government is also staunchly pursuing the development of another type of physical infrastructure to facilitate globalized production: By late 2018, 11 large state industrial parks were commencing operations or being 
built in several cities across the country, mostly specialized in export-oriented clothing production (Map 10.1). These parks are developed by the Industrial Park Development Corporation (IPDC) in close cooperation with the Ethiopian Investment Commission (EIC). China's experience in special economic zone development is an important reference (UNDP and IPRCC 2015; Weldesilassie et al. 2017; Zhang et al. 2018), and for the design and construction of the parks, mostly experienced Chinese state companies such as the China Communications Construction Company (CCCC) and CCECC were commissioned. The parks offer very competitive conditions for leasing sheds or land, cheap water, and energy supply to foreign investors. ${ }^{2}$ In addition, there are several private industrial park developments, including significant Chinese investment projects such as the Eastern Industry Zone south-east of Addis (Dannenberg, Yejoo, and Schiller 2013; Giannecchini and Taylor 2018) and major industrial zones in Adama and Dire Dawa. All these projects are located on or near the privileged rail and road connections established with Chinese financing and engineering capacities.

In terms of global clothing production networks, the industrial parks offer a physical platform attracting established suppliers to big European and US clothing brands and retailers, predominantly from South and East Asia, to move part of their sewing operations here. Transferring this segment of production requires the least amount of investment and commitment but still enables companies to profit from preferential trade frameworks with the USA and the EU, in addition to low production costs. In parallel, several big Chinese fabric producers are setting up facilities in some of the parks as potential suppliers to the sewing factories (on the importance of industry park clusters and established supplier relations, see Altenburg et al. 2020, 54-55, 60). This allows them to cut supply routes significantly while benefiting from the same incentives as export producers.

In terms of transnational actor constellations, the parks constitute arenas of collaboration between not only Ethiopian government institutions, transnational players from the clothing industry, and global construction companies, but also international banks and development agencies. Ethiopian authorities, international economic consultants, and development agencies advocate the industrial parks as high-potential locations for the labor-intensive clothing sector, as incubators for environmental sustainability and "good governance," and as profitable opportunities for investment and sourcing, as well as technology export from the agencies' home countries. ${ }^{3}$ However, observers point out the risk that nearly no backward or forward linkages to the domestic economy are being formed at such export processing enclaves (Nicolas 2017; Staritz, Plank, and Morris 2016; Weldesilassie et al. 2017; but see Altenburg et al. 2020, 58 for a cautious revision of this assessment). Beyond offering very low-wage jobs, the value captured in Ethiopia may therefore remain very low (Whitfield, Staritz, and Morris 2020) and is subject to the extreme volatility of the global clothing industry. 


\section{Mekelle: a commodity hub in the making?}

Mekelle city, capital of Tigray Regional State in northern Ethiopia, is an instructive case for studying how infrastructure provision contributes to shaping global production networks and how transnational actors become significant players in negotiating and physically transforming urban space. However, military conflict has flared up in the region in late 2020, critically affecting civilians and creating much uncertainty about the future. In late 2018, there were four large export-oriented industrial zones under construction on greenfield sites, all specializing in garment production and aspiring to employ more than 10,000 workers each (Map 10.2). In addition to the IPDC's Mekelle Industry Park (MIP), private industrial parks and major clothing production complexes were being developed by investors from India, the UAE, Bangladesh, and Italy. Similar global production relations are formed as in other Ethiopian industrial parks: Mostly suppliers of ready-made garments to global brands or retailers in Europe and North America are expanding their production from South-East Asia or Egypt to Mekelle in order to profit from preferential trade, incentives, and low costs. Initially, all supplies are imported, but some companies plan to set up vertically integrated factories. Moving production to Mekelle was supported and even pushed by major European clothing retailers with a fresh Corporate Social Responsibility strategy, seeking a new and cheap production region not yet associated with inhuman and dangerous working conditions. These retailers and brands entered notable collaborations with development agencies from European countries like Swedfund or Germany's Ministry for Development Cooperation, for example, in projects to train and educate workers.

Our research focuses on MIP as a physical infrastructure for global clothing production, developed by Ethiopian government authorities in cooperation with international partners. The regional government delineated an area of 1000 ha for textile and garment production at a site between villages in the south-west periphery of Mekelle (Map 10.2). The first development phase of 75 ha with 15 turnkey sheds, offices, road, and engineering networks was designed and built by Chinese contractor CCCC, financed by Ethiopia's government. By 2018, the park commenced operations with sewing companies from India, Bangladesh, and Pakistan among the first tenants. A second construction phase of 163 ha is to be implemented through a loan contract with the European Investment Bank. However, due to the military conflict between Ethiopia's federal government and Tigray Regional that started in late 2020, operations in the park were temporarily suspended and also the implementation of the infrastructure projects aiming at coupling Mekelle with global production networks is highly uncertain.

MIP constitutes a large monofunctional enclave of export manufacturing in a dry landscape of seasonal pasture land dotted with small village houses in traditional stone masonry, where water scarcity was already an issue before the arrival of large industrial consumers (PWC, IPE Global Triple Line, and EDRI 2017). Plugging this enclave into transport and supply networks, and establishing the urban fabric of social reproduction necessary to keep transnational commodity 


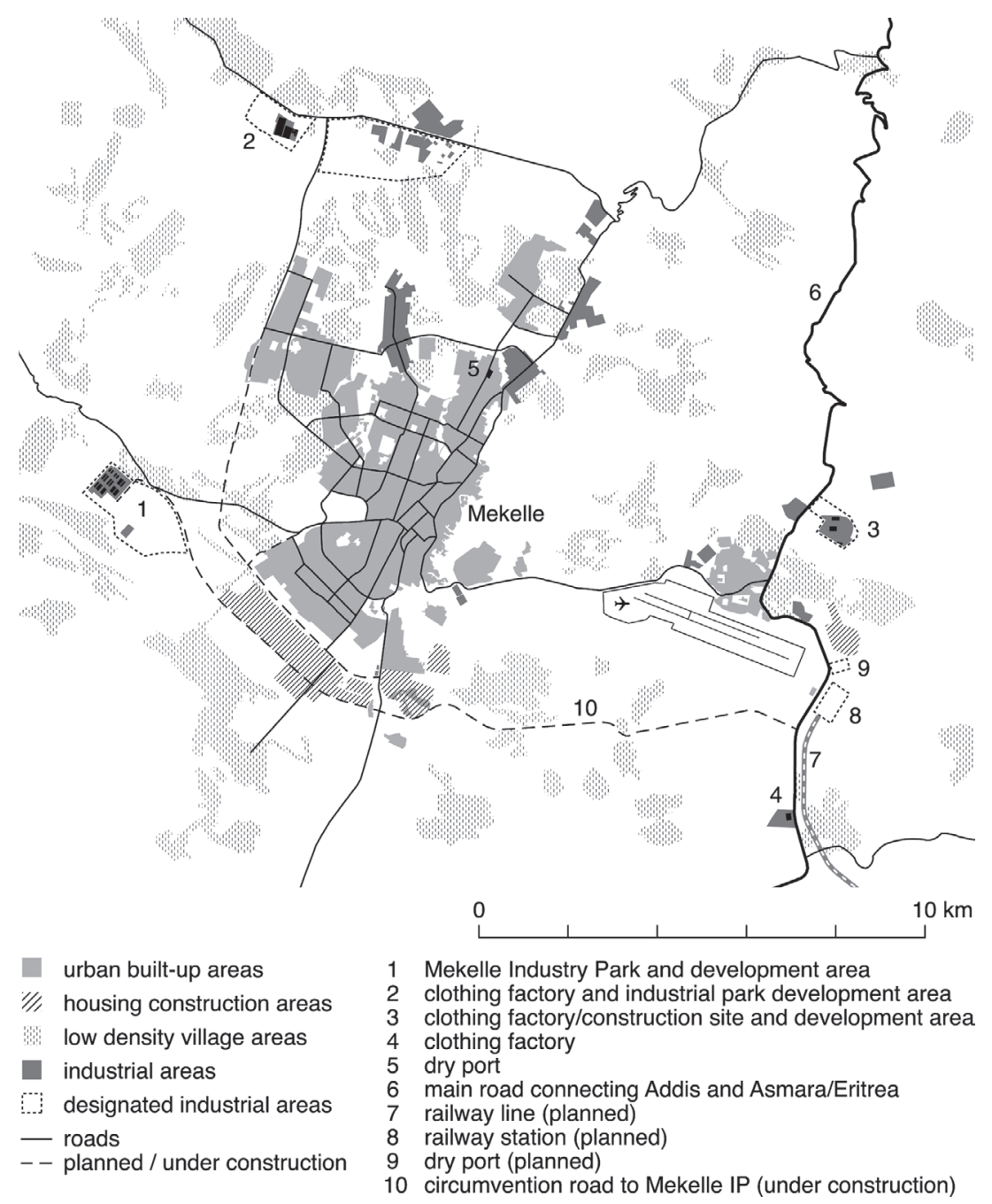

MAP 10.2 Infrastructures of manufacturing and circulation in Mekelle (2018)

Map: Anke Hagemann, Elke Beyer, Ilkim Er

Sources: Google Maps, OpenStreetMap, Industrial Parks Development Corporation

production running, emerges as a partly incremental process of spatial planning and infrastructure provision from the top down and bottom up. In conversation with the authors, local urban planners hinted at a rather retroactive integration of the industrial areas into structural planning. As in other Ethiopian industrial parks, housing for the expected tens of thousands of workers was still a matter of deliberation and improvisation: According to the park management, low-cost housing development schemes were still in search of funding, while some tenant companies 
had requested land on the park outskirts to build their own dormitories. At the time of our research, major transport infrastructure construction was under way in order to connect the export industry to the international ports (Map 10.2). In addition to the railway terminus planned relatively far east of the city center, adjacent to the main overland road, CCCC was building an $18 \mathrm{~km}$ circumvention road between MIP and the future road and rail junction. Close by, a new dry port for customs procedures and transferring containers from road to rail was in the planning stage-designed by CCCC for the Ethiopian state-owned Shipping and Logistics Service Enterprise (Kang'ereha 2017; PWC, IPE Global Triple Line, and EDRI 2017). Thus, one huge and globally active Chinese construction corporation acquired responsibility for the execution and design of most major infrastructure projects aspiring to transform the peri-urban landscape around Mekelle into an export commodity hub.

Marketing brochures for potential investors in Mekelle IP depict a high-standard manufacturing zone connected to global distribution networks by an environmentally friendly railway. Despite all the money already invested to create this physical infrastructure and conflictual land procurement negotiations, however, global supply chains to and from the emerging commodity hub might ultimately follow different routes: Railway construction was interrupted in 2019 due to financial difficulties, while the peace with Eritrea seemed to soon allow goods to be shipped through Massawa port, at a half-day truck-ride of just about $400 \mathrm{~km}$, much closer to Mekelle than Djibouti at $670 \mathrm{~km}$.

As large export production enclaves are built and linked to privileged transport corridors, the formation of global production networks and transnational involvement in infrastructure provisioning are closely linked and markedly impact urban development in Mekelle. We argue for a closer investigation of how urban spaces are co-produced in this asymmetrical interaction between transnational, national, and municipal actors with potentially diverse agendas as well as the workers and local residents whose changing livelihoods are fundamentally implicated in the major spatial transformations taking place.

\section{Case 2: infrastructures for soybean processing and logistics in Argentina}

Argentina's economy has been based on the export of agricultural products for more than a century. Soybeans and by-products in particular made up more than $25 \%$ of the national exports in past years, creating a critical dependency on the global market. The country is the world's third largest producer of soybeans, and the largest for processed soy-based products (Berndt and Bernhold 2017). The most important market for Argentina's grains is the PR China, receiving 96\% of the country's soybean exports in 2018 (Bolsa de Comercio de Rosario 2019a). The soy industry is mostly organized in global production networks, and the sub-sectors of soybean processing and trading are dominated by a few large, vertically integrated, partly transnational companies (Gómez Lende and Velázquez 2018). The soy boom 
has transformed Argentina's landscape and social structure in recent decades by re-enforcing existing and creating new patterns of inequality. For instance, processes of "accumulation by dispossession" (Harvey 2006) occur in relation to the spatial expansion of industrialized soy cultivation, and its intensive pesticide use and monoculture farming cause environmental degradation. In this context, former peasants have been excluded from participating in agricultural activities, and migration to cities has increased (Lapegna 2017; Gras 2013).

Transport infrastructure development has been mired in extractivism and particularly the agroindustry in Argentina: Major road and railway corridors as well as inland waterways primarily connect growing areas to ports that provide links to global markets. The expansion of transportation networks is of great importance with regard to integrating new territories into global agroindustrial production networks (Gómez Lende and Velázquez 2018). The agroindustry is also an important player in transport operations, as large producers and traders have made the operation of port terminals, railway lines, and truck fleets part of their business. Currently, soy is mostly transported by truck (Gómez Lende and Velázquez 2018) as the railway network has eroded since the late 20th century due to neoliberal restructuring and the promotion of road-borne transport. Our research focuses on the state-run Belgrano Cargas cargo rail network. Its main corridor is currently being renovated in order to improve connectivity between the major grain ports in the Rosario area and the agrarian regions by reducing travel times. The renovation project is being financed by the Argentinean state and a USD 4 billion loan from the China Development Bank Corporation and the Industrial and Commercial Bank of China Limited. Under the direction of Argentina's federal transport ministry and coordinated by a state-owned railway infrastructure company, project implementation was commissioned to the China Machinery and Engineering Corporation (CMEC) (Ministerio de Transporte 2017). Construction work is being carried out by Argentinean companies, but the financing contract for the Belgrano Cargas project foresees the acquisition of rolling stock and construction materials from Chinese companies. In December 2019, about half of the targeted $1845 \mathrm{~km}$ railway line had been renovated. The project is part of larger Chinese infrastructure initiatives in Argentina, such as loans by state-owned Chinese banks for further railway projects and energy infrastructures (InterAmerican Dialogue 2019).

\section{Gran Rosario: a global center of the soy industry}

Gran Rosario is the third largest metropolitan region in Argentina with about 1.3 million inhabitants. The city evolved around a port at the Paraná river and has been a center of grain trade, transport, and processing for many decades. Its urban form has been shaped by infrastructures such as railway lines, grain ports, silos, and mills, which made it the central hub connecting the vast agricultural areas of the Argentinean Pampa with global markets (Galimberti 2015). The metropolitan area 
of Rosario stretches more than $60 \mathrm{~km}$ along the bank of the Paraná river and incorporates around 20 deep-water ports that account for around $80 \%$ of the country's exports of grains and by-products (Bolsa de Comercio de Rosario 2019b). Many of these complexes also comprise processing facilities such as soy crushing plants and bio diesel refineries. Compared to other major soy-producing countries, the facilities in Argentina are characterized by large sizes and high volumes (Schweitzer 2011). Altogether, the region represents one of the world's centers for the shipping and crushing of soybeans.

On the northern fringe of the Rosario metropolitan region, the Belgrano Cargas project also implies the provisioning of new rail tracks to the ports and a large new rail yard in the small town of Timbúes (Map 10.3). This section will be financed by the three international companies operating the ports and processing facilities and those actors developing new facilities at the same location: China Oil and Foodstuffs Corporation (COFCO), Aceitera General Deheza (AGD), Renova, Dreyfus, and Asociación de Cooperativas Argentinas (ACA). ${ }^{4}$ COFCO, a Chinese state-owned food processing and trading company, is a major actor in the context of infrastructure development in the Rosario area and has become an important player in Argentina's agroindustry in recent years through the acquisition of two large competitors operating large facilities in Rosario. At its site in Timbúes, COFCO is planning to expand its processing and logistics complex.

The companies whose terminals are being connected to the Belgrano Cargas network have been involved in the development of the project in several other ways: They are all members of the Rosario Board of Trade, a local business organization representing the interests of the agroindustry and considered to be highly influential in local, provincial, and national politics (authors' interviews 2018). In addition, most companies with facilities in Timbúes are listed as customers of Trenes Argentinos Carga, a state-owned freight railway company. Grains and byproducts made up between 50 and $80 \%$ of the volume transported by the Belgrano Cargas network in the past ten years. Thus, it can be assumed that these companies generate a significant part of the cargo transported and also the future demand for which the services are planned.

The railway project and the expansion of port capacities in Gran Rosario contribute to the consolidation of the region's function as a central commodity hub within the global soy production networks, and thereby to the industry's spatial concentration. However, the railway line, which serves almost exclusively the needs of the export-oriented primary sector, and the other massive infrastructures provided for the processing and transportation of grains reinforce Argentina's extractivist development model, which produces social and environmental problems in the regions where the crops are cultivated and the urban areas where the processing and logistics facilities are located (Schweitzer 2017). In the case of Gran Rosario, the impacts of the operation and provision of infrastructures include pollution and massive traffic congestion in the suburbs as well as the displacement of small-scale fishery at the river banks (Schweitzer 2017; Cloquell et al. 2011; Roldán and Godoy 2020). 


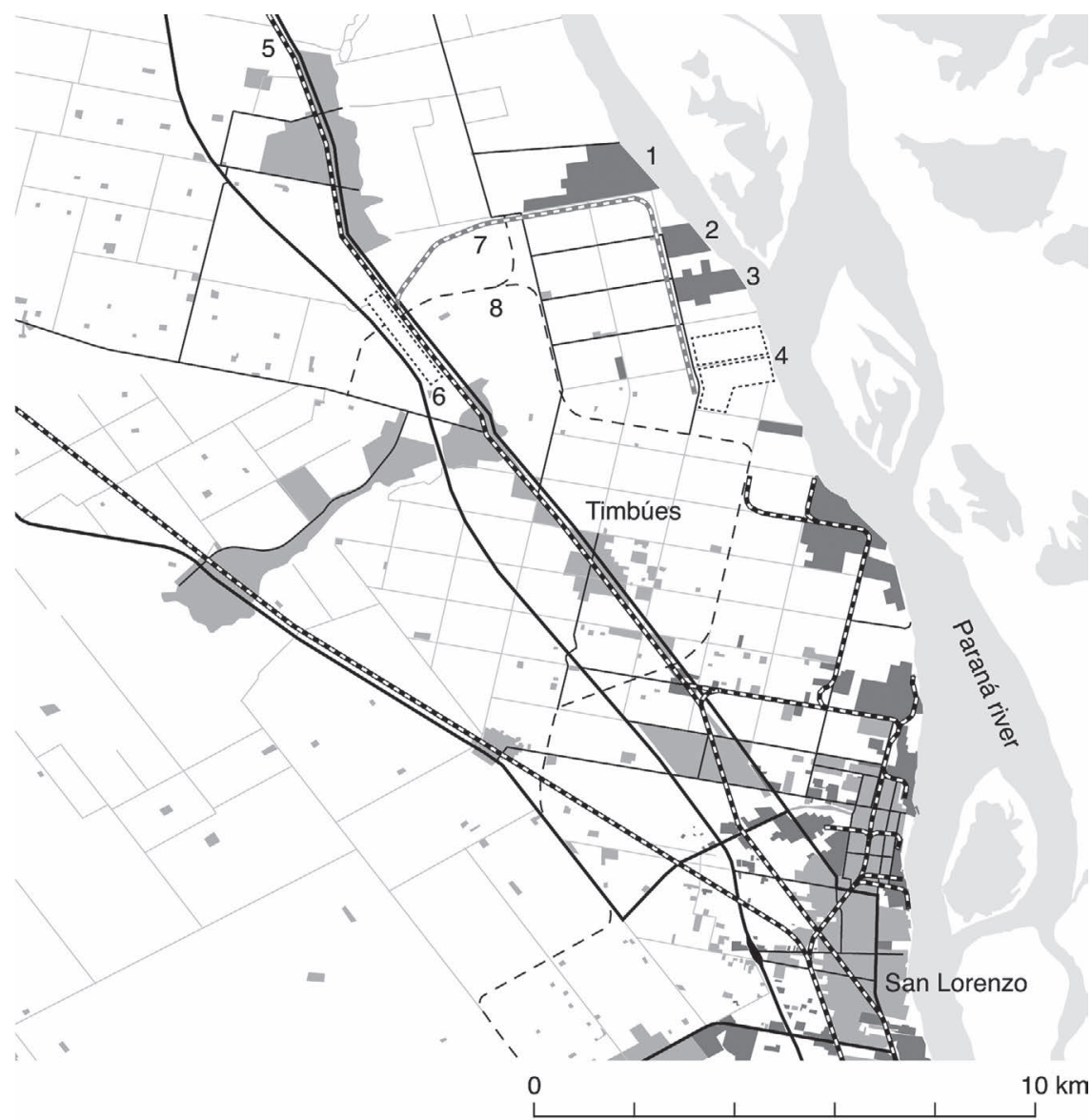

built-up areas

- " farms / agrarian structures industrial areas

f... future development areas

— roads

- - - planned

n... railway

manned soy processing and port facilities:

1 Renova

2 LDC

3 COFCO

4 ACA and AGD development areas

transport infrastructures:

5 Belgrano Cargas railway

6 planned railyard

7 planned railway

8 planned road

MAP 10.3 Infrastructures of manufacturing and circulation in the north of Gran Rosario (2018)

Map: Anke Hagemann, Ilkim Er, Lucas Elsner

Sources: Google Maps, OpenStreetMap, Vialidad Nacional, Trenes Argentinos Infraestructura 


\section{Spatial transformation through infrastructures of global commodity production and transnational actor constellations}

It has been illustrated how the provisioning of large physical infrastructures is deeply entangled in the integration of Mekelle and Rosario in global production networks and thus the exploitation and reproduction of spatial inequalities. Looking beyond the two cases, this is not such a new insight but an aspect that has widely been neglected in GPN research. In order to position the two places within specific global production networks as a part of national developmental strategies, the urban areas of Mekelle and Rosario are currently being reconfigured as commodity hubs through the deployment of infrastructure projects that are among the largest in the respective regions. In both cases, Chinese construction engineering companies and banks play a key role among multiple international and domestic actors. They orchestrate a large network of Chinese companies from the infrastructure, transportation, and construction sector involved in the projects by acting as intermediaries for loans and by coordinating the provision of construction materials and technology as well as the respective expertise from the PRC.

The urban impact of the infrastructure projects is massive in both cases - in terms of land and resource consumption, land-use changes, social impacts including ruralurban migration, the improvisation of affordable housing for workers, and environmental externalities. The large-scale spatial interventions constitute important vectors of spatial transformation and future urbanization processes. Obviously, the spatial logics and transnational actor constellations of global clothing production and the soybean agroindustry differ in significant ways. Enhancing connectivity in Rosario promises stabilization of China's import supply with agricultural staples and qualifies the region's function as the industry's major hub. In contrast, infrastructure in Mekelle and other Ethiopian cities is set up to encourage the relocation of production capacities in the low-wage textile industry and simultaneously foster the export of commodities, industry supplies, and construction technology from China to Ethiopia. In both cases, these relations are physically inscribed in the provided infrastructures and thereby in the specific built environments constituting transnational urban spaces. The ports and railway infrastructures in Rosario are constructed according to the specific technical demands of grain shipping, and the transportation network is designed to enable unidirectional flows from the agricultural hinterlands through the ports in Rosario to global markets. In Ethiopia, large clothing production facilities are set up within reach of international ports and with advanced "green" and automated technology to meet global buyers' demands, but only basic dormitory accommodation is provided for workers arriving from distant villages to work at the lowest wages to be found among clothing exporter countries (Altenburg et al. 2020, 57). Considering the spatial transformation of the peri-urban landscapes under study, instances of "splintering urbanism" (Graham and Marvin 2001) can be observed in both cases: Niches and enclaves of globalized production benefit from infrastructure provision enabling privileged connections, while the municipalities and their inhabitants are confronted with negative externalities, such as increased 
water scarcity, pollution, housing needs, and high traffic volumes. At a national and regional level, the infrastructure initiatives discussed in this chapter primarily strengthen major urban centers, fostering processes of urban-rural polarization.

Although the precise roles and power relations of corporate and state actors vary, the two cases reveal instructive similarities regarding the governance of infrastructure provisioning in the context of larger bilateral cooperation initiatives with the PR China and other international partners. In both cases, the leading role of planning authorities at the national level results in challenges for planning on an urban and regional scale. Transnational enterprises are deeply involved in financing, ownership, operation, and construction of the infrastructures under study and thus in channeling the global flows of commodities (inter alia to and from China) and the value generation enabled by these structures. In this specific way, the emerging urban spaces and the modalities of spatial transformation and commodity production must be understood as transnational and relational. Studying the provision of infrastructures for global production networks substantially adds to the knowledge on the precise links that mediate and co-produce interdependent dynamics of uneven spatial development and the resulting inequalities. The discussion of the two case studies has shown that examining the transnational actor constellations of infrastructure provision is crucial for understanding the uneven spatialities of global production networks as both networks are closely entangled. We argue that an in-depth analysis of these spatialities requires an integrated approach, taking into account both the networks of commodity production and the networks of infrastructure provision in order to fully comprehend their interdependent character. Such an analysis also offers valuable insights for spatial planning, specifically when it comes to aspirations to participate in global production networks and the resulting challenges related to the (re-)production of uneven spatialities.

\section{Notes}

1 Including findings of the "Transnational Production Spaces" research project (DFG no.: MI 1893/2-1) on clothing industry sites in Turkey, Bulgaria, and Ethiopia.

2 As "renewable" power supply to manufacturing industries, giant hydropower dams are under construction on the Blue Nile and the Omo rivers.

3 We would like to thank our research partners, Melaku Tanku Gebremariam and Eyassu Kumera, for sharing their observations at the 2019 International Conference on Sustainable Industrial Areas in Addis, organized by the German Organization for the Development of Cooperation in partnership with Ethiopia's IPDC and EIC, the UK Department for International Development, and the International Finance Corporation.

4 Together these companies accounted for $43 \%$ of Argentina's exports of grains and byproducts in 2018 (Bolsa de Comercio de Rosario 2019a).

\section{References}

Altenburg, Tilmann, Xiao Chen, Wilfried Lütkenhorst, Cornelia Staritz, and Lindsay Whitfield. 2020. "Exporting out of China or out of Africa? Automation versus Relocation in the Global Clothing Industry." Discussion Paper. Bonn: Deutsches Institut für Entwicklungspolitik. 
Bair, Jennifer. 2005. "Global Capitalism and Commodity Chains: Looking Back, Going Forward.” Competition \& Change 9 (2): 153-180.

Bair, Jennifer, and Marion Werner. 2011. "Commodity Chains and the Uneven Geographies of Global Capitalism: A Disarticulations Perspective." Environment and Planning A 43 (5): 988-997.

Berndt, Christian, and Christine Bernhold. 2017. "Lateinamerikanischer Neostrukturalismus: Sojaboom und wirtschaftliche Konzentration in Argentinien." Zeitschrift für Wirtschaftsgeographie 62 (1): 30-45.

Beyer, Elke, and Anke Hagemann. 2018. "'Getting It Right from the Start'? Building Spaces of Transnational Clothing Production in Ethiopia." Trialog 130-131: 63-71.

Bolsa de Comercio de Rosario. 2019a. "Informativo Semanal. AÑO XXXVI-Nº Edición 1898."Accessed June 28,2020. www.bcr.com.ar/es/mercados/investigacion-y-desarrollo/ informativo-semanal/noticias-informativo-semanal/quienes-fueron.

Bolsa de Comercio de Rosario. 2019b. "Informativo Semanal. AÑO XXXVII-N Edición 1921.”Accessed June 28,2020. www.bcr.com.ar/es/mercados/investigacion-y-desarrollo/ informativo-semanal/noticias-informativo-semanal/las-terminales.

Cidell, Julie. 2015. "The Role of Major Infrastructure in Subregional Economic Development: An Empirical Study of Airports and Cities." Journal of Economic Geography 15 (6): 1125-1144.

Cloquell Silvia, Roxana Albanesi, María Elena Nogueira, and Patricia Propersi. 2011. "Las localidades del sur santafesino. Factores favorables y desfavorables de la imbricación urbano-rural." Revista Interdisciplinaria de Estudios Agrarios 35: 5-34.

Coe, Neil M., and Henry W. Yeung. 2015. Global Production Networks: Theorizing Economic Development in an Interconnected World. Oxford: Oxford University Press.

Dannenberg, Peter, Kim Yejoo, and Daniel Schiller. 2013. "Chinese Special Economic Zones in Africa: A New Species of Globalisation?" African East-Asian Affairs 2: 4-14.

Delz, Sascha. 2015. "Development Cooperation at All Costs: How Global Actors and Concepts Influence Urban and Rural Transformation: Case Studies from Ethiopia.” $\mathrm{PhD}$ diss., ETH Zurich.

Delz, Sascha. 2016. "Who Built This? China, China, China! Expanding the Chinese Economy through Mutual Benefit and Infrastructure Construction." In Cities of ChangeAddis Ababa. Transformation Strategies for Urban Territories in the 21st Century, edited by Marc Angélil and Dirk Hebel, 198-206. Basel: Birkhäuser.

Easterling, Keller. 2014. Extrastatecraft: The Power of Infrastructure Space. New York: Verso.

Ethiopian Investment Commission. 2020. "Realizing New Productive Capacity in Ethiopia’s Textiles and Apparel Sector:Strategy and Policy Recommendations." Accessed September 2020. www.investethiopia.gov.et/images/Covid-19Response/Covid-19Resources/publications_May-20/Realizing-New-Productive-Capacity-in-Ethiopia-Textiles-ApparelSecctor-Strategy-Policy-Recommendations.pdf.

Foster, Vivien, and Elvira Morella. 2011. "Ethiopia's Infrastructure. A Continental Perspective." Policy Research Working Paper No. 5595. Washington, DC: The World Bank Africa Region Sustainable Development Department.

Galimberti, Cecilia. 2015. "La reinvención del Río Procesos de transformación de la ribera de la Región Metropolitana de Rosario, Argentina.” PhD diss., Universidad Nacional de Rosario.

Gereffi, Gary, and Miguel Korzeniewicz, eds. 1994. Commodity Chains and Global Capitalism. Westport: Praeger.

Giannecchini, Philip, and Ian Taylor. 2018. "The Eastern Industrial Zone in Ethiopia: Catalyst for Development?” Geoforum 88: 28-35.

Giraudo, Maria Eugenia. 2015. "Commodity Hubs: Production of Space and New Geographies of Capital.” Alternautas 2 (1): 79-87. 
Gómez Lende, Sebastian, and Guillermo Velázquez. 2018. "Soybean Agribusiness in Argentina (1990-2015): Socio-Economic, Territorial, Environmental, and Political Implications." In Agricultural Value Chain, edited by Gokhan Egilmez, 117-136. London: InTech.

Graham, Steven, and Simon Marvin. 2001. Splintering Urbanism: Networked Infrastructures, Technological Mobilities and the Urban Condition. New York: Routledge.

Gras, Carla. 2013. "Agronegocios en el Cono Sur." desiguALdades.net Working Paper Series No. 50. Berlin: desiguALdades.net International Research Network on Interdependent Inequalities in Latin America.

Grubbauer, Monika. 2015. "Circulating Knowledge, Marketization and Norm-Making: International Developers and Construction Firms in Eastern Europe since 2000." Global Networks 15 (3): 288-306.

Hagemann, Anke, and Elke Beyer. 2020. "Globalizing Urban Research, Grounding Global Production Networks: Transnational Clothing Production and the Built Environment." Articulo-Journal of Urban Research 21.

Harris, Andrew. 2013. "Concrete Geographies: Assembling Global Mumbai through Transport Infrastructure." City 17 (3): 343-360.

Harvey, David. 2006. Spaces of Global Capitalism. London: Verso.

Henderson, Jeffrey, Peter Dicken, Martin Hess, Neil M. Coe, and Henry W. Yeung. 2002. "Global Production Networks and the Analysis of Economic Development." Review of International Political Economy 9 (3): 436-464.

Inter-American Dialogue. 2019. “China-Latin America Finance Database.” Accessed June 28, 2020. www.thedialogue.org/map_list/.

Jalles d'Orey, Maria Ana, and Annalisa Prizzon. 2017. “An 'Age of Choice' for Infrastructure Financing? Evidence from Ethiopia." ODI Report, April 2017. London: ODI.

Kanai, Miguel J., and Seth Schindler. 2018. "Peri-urban Promises of Connectivity: Linking Project-Led Polycentrism to the Infrastructure Scramble." Environment and Planning A 51 (2): 302-322.

Kang'ereha, Dorcas. 2017. “Ethiopia’s US \$100m Dry Port Design Concluded.” Accessed June 28, 2020. https://constructionreviewonline.com/2017/11/ethiopias-us-100m-dryport-design-concluded/.

Kleibert, Jana M., and Rory Horner. 2018. "Geographies of Global Production Networks." In Handbook on Geographies of Globalization, edited by Robert Kloosterman, Virginie Mamadouh, and Pieter Terhorst, 222-234. Cheltenham: Edward Elgar Publishing.

Krätke Stefan, Kathrin Wildner, and Stephan Lanz, eds. 2012. Transnationalism and Urbanism. New York: Routledge.

Lapegna, Pablo. 2017. "The Political Economy of the Agro-Export Boom under the Kirchners: Hegemony and Passive Revolution in Argentina." Journal of Agrarian Change 17 (2): 313-329.

Lara, Juan D. de. 2012. "Goods Movement and Metropolitan Inequality: Global Restructuring, Commodity Flows, and Metropolitan Development." In Cities, Regions and Flows, edited by Peter V. Hall and Markus Hesse, 76-91. New York: Routledge.

LeCavalier, Jesse. 2016. The Rule of Logistics: Walmart and the Architecture of Fulfillment. Minneapolis: University of Minnesota Press.

Ministerio de Transporte. 2017. “El Gobierno Nacional amplió USD 1600 M el crédito para recuperar el FFCC Belgrano Cargas.” Accessed December 14, 2018. www.argentina. gob.ar/noticias/el-gobierno-nacional-amplio-usd-1600-m-el-credito-para-recuperarel-ffcc-belgrano-cargas.

National Planning Commission. 2016. Growth and Transformation Plan II (2015/16-2019/20) Volume I: Main Text. Addis Ababa: National Planning Commission.

Nicolas, Françoise. 2017. “Chinese Investors in Ethiopia: The Perfect Match?” Notes de l'IFRI, March 2017. Paris: IFRI. 
Parnreiter, Christof. 2012. "Conceptualizing Transnational Urban Spaces: Multicentered Agency, Placeless Organizational Logics, and the Built Environment." In Transnationalism and Urbanism, edited by Stefan Krätke, Kathrin Wildner, and Stephan Lanz, 91-110. New York: Routledge.

Phelps, Nicholas A., Miguel Atienza, and Martin Arias. 2018 "An Invitation to the Dark Side of Economic Geography.” Environment and Planning A 50 (1): 236-244.

PWC, IPE Global Triple Line, and EDRI. 2017. "Green Climate Compatible Urban Industrial Development in Ethiopia. Strategy and Projects for the Kombolcha-Mekele Industrial Corridor. Final Report." Climate \& Development Knowledge Network. Accessed June 28, 2020. https://cdkn.org/wp-content/uploads/2018/02/Final-Reporting-ClimateCompatible-Urban-Industrial-project-development-and-Investment-Plan.pdf.

Rode, Philipp, Biruk Terrefe, and Nuno F. da Cruz. 2020. "Cities and the Governance of Transport Interfaces: Ethiopia’s New Rail Systems.” Transport Policy 91 (June): 76-94.

Roldán, Diego, and Sebastián Godoy. 2020. "Conflictos territoriales y culturales en la renovación del frente costero, Rosario (Argentina).” EURE 138: 95-116.

Schweitzer, Mariana. 2011. "El transporte en la producción del territorio. Corredores de transporte: La IIRSA y la hidrovía Paraná-Paraguay." Jornadas Regionales de Información Geográfica y Ordenamiento Territorial 2: 125-136.

Schweitzer, Mariana. 2017. "San Lorenzo y Puerto General San Martín. Territorios atravesados por dinámicas globales.” América Latina Hoy 75: 101-124.

Sheppard, Eric. 2016. Limits to Globalization: Disruptive Geographies of Capitalist Development. Oxford: Oxford University Press.

Smith, Neil. 1984. Uneven Development: Nature, Capital, and the Production of Space. Oxford: Blackwell.

Söderström, Ola. 2014. Cities in Relations. Trajectories of Urban Development in Hanoi and Ouagadougou. Chichester: Wiley Blackwell.

Staritz, Cornelia, Leonhard Plank, and Mike Morris. 2016. "Global Value Chains, Industrial Policy, and Sustainable Development-Ethiopia's Apparel Export Sector.” Country Case Study. Inclusive Economic Transformation, November 2016. Vienna: ICTSD.

Sun,Yun. 2017. "China and the East Africa Railways:BeyondFullIndustry Chain Export."Brookings. Accessed June 28, 2020. www.brookings.edu/blog/africa-in-focus/2017/07/06/ china-and-the-east-africa-railways-beyond-full-industry-chain-export/.

UNDP Ethiopia. 2017. National Logistics Strategy. Addis Ababa: UNDP Ethiopia.

UNDP and IPRCC. 2015. "If Africa Builds Nests, Will the Birds Come? Comparative Study on Special Economic Zones in Africa and China." Working Paper Series No. 06. Beijing: UNDP and IPRCC.

Weldesilassie, Alebel B., Mulu Gebreeyesus, Girum Abebe, and Berihu Aseffa Gebrehiwot. 2017. "Study on Industrial Park Development: Issues, Practices and Lessons for Ethiopia." Research Reports No. 29. Addis Ababa: Ethiopian Development Research Institute.

Werner, Marion. 2016. "Global Production Networks and Uneven Development: Exploring Geographies of Devaluation, Disinvestment, and Exclusion." Geography Compass 10 (11): 457-469.

Whitfield, Lindsay, Cornelia Staritz, and Mike Morris. 2020. "Global Value Chains, Industrial Policy and Economic Upgrading in Ethiopia's Apparel Sector." Development and Change 51 (4): 1018-1043.

Zhang, Xiaodi, Dejene Tezera, Ciyong Zou, Zhen Wang, Jie Zhao, and Eneyew Abera Gebremenfas. 2018. "Industrial Park Development in Ethiopia. Case Study Report." Department of Policy, Research and Statistics Working Paper No. 21/2018. Vienna: UNIDO. 